\title{
ARTICLE
}

Nutrition and health (including climate and ecological aspects)

\section{Prevalence and predictors of vitamin D deficiency in a nationally representative sample of Australian adolescents and young adults}

\author{
Kahlea Horton-French ${ }^{1} \cdot$ Eleanor Dunlop $\mathbb{1}^{1} \cdot$ Robyn M. Lucas $\mathbb{D}^{2,3} \cdot$ Gavin Pereira $\mathbb{D}^{1,4,5} \cdot$ Lucinda J. Black $\mathbb{1}^{1}$
}

Received: 3 September 2020 / Revised: 27 January 2021 / Accepted: 3 February 2021 / Published online: 1 March 2021

(c) The Author(s), under exclusive licence to Springer Nature Limited 2021

\begin{abstract}
Background/Objectives Vitamin D deficiency is a public health concern worldwide. Maintaining vitamin D sufficiency during growth periods is essential. We aimed to determine the prevalence and predictors of vitamin D deficiency in Australian adolescents and young adults.

Subject/Methods We used data from adolescents (12-17 years, $n=692)$ and young adults $(18-24$ years, $n=400)$ who participated in the nationally representative 2011-2013 Australian Health Survey. Serum 25-hydroxyvitamin D concentrations were measured using a method certified to international standards, with prevalence reported for $<50$ (vitamin D deficiency), $50-<75, \geq 75$ and $>125 \mathrm{nmol} / \mathrm{L}$. Independent predictors of vitamin $\mathrm{D}$ deficiency were determined using a surveyweighted Poisson regression model.

Results Overall, $17 \%$ of adolescents and $32 \%$ of young adults were vitamin D deficient. In models adjusted for sex, age, region of birth, socioeconomic status, BMI and season (and education, smoking status and physical activity in young adults only), the prevalence ratio (PR) for vitamin D deficiency was more than double in participants born outside Australia (adolescents: PR 2.46; 95\% confidence interval $(\mathrm{CI})=1.59,3.81$; young adults: $\mathrm{PR} 2.12 ; 95 \% \mathrm{CI}=1.46,3.07$ ), and also varied by season (adolescents: spring vs summer PR 2.47;95\% CI $=1.22,5.01$ and winter vs summer PR 2.01; $95 \% \mathrm{CI}=$ 1.03, 3.92; young adults: winter vs summer; PR 3.32; $95 \% \mathrm{CI}=1.69,6.53$ ). Other predictors of vitamin $\mathrm{D}$ deficiency were overweight compared with healthy weight (adolescents) and lower physical activity (young adults).

Conclusions Strategies based on safe sun exposure and dietary approaches are needed to achieve and maintain adequate vitamin D status, particularly in young adults.
\end{abstract}

Supplementary information The online version contains supplementary material available at https://doi.org/10.1038/s41430021-00880-y.

Lucinda J. Black

lucinda.black@curtin.edu.au

1 Curtin School of Population Health, Curtin University, Bentley, WA, Australia

2 National Centre for Epidemiology and Population Health, Research School of Population Health, Australian National University, Acton, ACT, Australia

3 Centre for Ophthalmology and Visual Science, University of Western Australia, Crawley, WA, Australia

4 Telethon Kids Institute, Nedlands, WA, Australia

5 Centre for Fertility and Health $(\mathrm{CeFH})$, Norwegian Institute of Public Health, Oslo, Norway

\section{Introduction}

Vitamin D is essential for bone health: the active form increases intestinal calcium absorption and promotes bone maturation. Childhood and adolescence are an important time to accrue bone mass and density to ensure maximal peak bone mass is achieved by young adulthood, since low peak bone mass leads to increased risk of fracture and osteoporosis later in life [1]. Given the essential role of vitamin $\mathrm{D}$ in bone health, it is important to monitor younger age groups where developmental periods represent a critical time for maintaining vitamin D adequacy [1]. As vitamin D supplements may be beneficial to mother and child during pregnancy [2], maintenance of adequate vitamin D status remains important for women during young adulthood. Vitamin D supplementation has also been shown to be protective against respiratory infections [3] and may reduce risk of COVID-19 infection and associated adverse outcomes [4]. 
Studies from around the world, covering a range of climates, report concerning high prevalence of vitamin D deficiency in adolescents and young adults. Three nationally representative studies in younger age groups in the USA reported the prevalence of vitamin D deficiency as $9 \%$ in 1-21 year olds (serum 25(OH)D concentrations < $37.5 \mathrm{nmol} / \mathrm{L}$ ) [5], 14\% in 12-19 year olds (serum 25(OH)D concentrations $<50 \mathrm{nmol} / \mathrm{L}$ ) [6] and $32 \%$ in $12-17$ year olds (serum 25(OH)D concentrations $<50 \mathrm{nmol} / \mathrm{L}$ ) [7] (Supplementary Table 1). A nationally representative Iranian study reported a high prevalence of deficiency $(40 \%)$ in participants aged 10-18 years (serum 25(OH)D concentrations < $25 \mathrm{nmol} / \mathrm{L}$ ) [8]. Of 188 participants (aged 12-13 years) included in a Korean study, $94 \%$ were vitamin D deficient [9], with a similar prevalence $(97 \%)$ reported in Chinese 12-15 year olds [10], Saudi Arabian 6-17 year olds (100\%) [11] and Turkish 4-16 year olds (98\%) [12] (all serum 25 $(\mathrm{OH}) \mathrm{D}$ concentration $<50 \mathrm{nmol} / \mathrm{L})$. The aforementioned studies do not appear to have adjusted for season.

One challenge in estimating the prevalence of vitamin D deficiency is that assays return highly variable results [13-16]. Previous studies have used a range of assays that have not been standardized to the reference measurement procedures developed by the National Institute of Standards and Technology, Ghent University, and the US Centers for Disease Control and Prevention (referred to as RMPs hereafter) $[17,18]$. This limits the validity of the prevalence estimates in previous studies.

The 2011-2013 Australian Health Survey (AHS) was the first nationally representative Australian survey to measure serum $25(\mathrm{OH}) \mathrm{D}$ concentrations, and these were measured using an assay certified to the RMPs. Using data from the AHS, we previously reported prevalence and predictors of vitamin D deficiency in Australian adults aged $\geq 25$ years [19]. We found that vitamin D deficiency was not uncommon $(20 \%)$, despite the opportunity for ultraviolet (UV) irradiation being relatively high in many regions of Australia, compared to many other countries. In this study, we aimed to determine the prevalence and predictors of vitamin D deficiency in Australian adolescents (12-17 years) and young adults (18-24 years) using data from the AHS.

\section{Subjects and methods}

\section{Study design and population}

This cross-sectional study used data from the 2011-2013 AHS, which comprised the National Health Survey (NHS), the National Nutrition and Physical Activity Survey (NNPAS), and the National Health Measures Survey (NHMS). Full details can be found elsewhere [20]. The AHS is based on a stratified, multistage area sample of private households, with each household assigned an analytical weight to account for the probability of inclusion. Core information was collected from all participants: household structure, demographics, self-reported health status and body mass, smoking status, anthropometric measurements (height, weight, waist, BMI [weight (kg)/ height $\left.\left.(\mathrm{m})^{2}\right]\right)$, fruit, vegetable and salt intakes, blood pressure, female life stage and selected health conditions. Participants were then randomly assigned to the NHS ( $n=$ $20,426)$, where health and medical information was collected, or the NNPAS $(n=12,153)$, where information regarding diet and physical activity was collected. Data were collected by a trained interviewer from the Australian Bureau of Statistics (ABS) through face-to-face interviews. Participants aged $\geq 5$ years were invited to take part in the NHMS ( $n=11,246$ ), which involved collecting blood and urine samples to measure various nutritional and biochemical biomarkers. Blood samples were collected only from those aged $\geq 12$ years $(n=10,401)$. The study was conducted in accordance with the Declaration of Helsinki. Interviews were conducted under the Census and Statistics Act 1905. For the NHMS component, ethics approval was granted by the Australian Government Department of Health and Ageing's Departmental Ethics Committee (approved in February 2011), and participants (or parents/ legal guardians in the case of children aged $<16$ years) gave written informed consent.

Participants self-reported their region of birth, location of residence (at the state/territory level), highest educational achievement (participants aged $\geq 15$ years) and smoking status (participants aged $\geq 15$ years) [20]. The 2011 Index of Relative Socioeconomic Disadvantage (IRSD) was used to describe socioeconomic status in deciles [20]. The IRSD is a socioeconomic index that summarises information relating to the social and economic resources of people and households within an area, with a score ranging from low (least disadvantage) to high (greatest disadvantage).

Young adult (aged 18-24 years) participants reported the total minutes undertaken in the physical activity categories of moderate activity, vigorous activity, walking for fitness, recreation or sport and walking for transport (physical activity was not measured in adolescents) [20]. Physical activity scores were based on the amount and level of physical activity undertaken for fitness, sport/recreation or transport in the past week. They were calculated as duration (minutes) multiplied by an intensity factor (walking for fitness or transport $=3.5$, moderate-level exercise/physical activity $=5.0$ and vigorous exercise/physical activity $=7.5$ ). The ABS then classified these scores as sedentary, low, moderate and high [20]. Weight $(\mathrm{kg})$ and height $(\mathrm{m})$ of both adolescents and young adults were measured by an interviewer and used to calculate body mass index BMI. Blood was taken using a standardised protocol [20]; date of blood 
collection was recorded. Serum 25(OH)D concentrations were measured at the Douglass Hanly Moir Laboratory (Sydney, Australia) using a liquid chromatography-tandem mass spectrometry method certified to the RMPs.

\section{Data management}

We categorised region of birth as "Australia" or "Other". States/territories were New South Wales, Victoria, Queensland, South Australia, Western Australia, Tasmania, Northern Territory and Australian Capital Territory. We categorised education as "high/primary/no school" (no nonschool qualification or level not determined and highest year of school completion), "certificate/diploma" (advanced diploma/diploma, certificate III/IV, certificate I/II, certificate not further defined) or "university" (postgraduate degree, graduate diploma/certificate, bachelor degree). We categorised smokers as "ex/non-smoker" (ex-smokers and never smoked) and "current" (current daily smoker, current smoker weekly, current smoker less than weekly). We categorised socioeconomic status into quintiles: "lowest quintile", "second quintile", "third quintile", "fourth quintile" and "highest quintile".

We categorised physical activity as "high", "moderate" or "low/sedentary". We categorised BMI as follows: "underweight/healthy weight" $\left(<25 \mathrm{~kg} / \mathrm{m}^{2}\right)$; "overweight" (25$\left.<30 \mathrm{~kg} / \mathrm{m}^{2}\right)$ or "obese" $\left(\geq 30 \mathrm{~kg} / \mathrm{m}^{2}\right)$, as per BMI score cutpoints defined for children by sex and age [20-22]. We categorised month of blood collection into seasons: "summer" (December-February), "autumn" (March-May), "winter" (June-August) or "spring" (September-November).

Vitamin D deficiency was defined as serum 25(OH)D concentration $<50 \mathrm{nmol} / \mathrm{L}$. For comparison with results from previous studies in the Australian population $[19,23,24]$, we also reported the proportion with serum 25 (OH)D concentrations $50-<75, \geq 75$ and $>125 \mathrm{nmol} / \mathrm{L}$. The Institute of Medicine states that serum $25(\mathrm{OH}) \mathrm{D}$ concentrations $>125 \mathrm{nmol} / \mathrm{L}$ are associated with increased risk of adverse health outcomes [25]; however, this may be a conservative threshold. A number of observational studies suggest better outcomes for some health conditions, such as breast cancer [26] and blood pressure [27], when serum 25 $(\mathrm{OH}) \mathrm{D}$ concentrations are $>125 \mathrm{nmol} / \mathrm{L}$.

\section{Statistical analysis}

We reported survey-weighted characteristics of participants, stratified by age group (12-17 and 18-24 years): number and proportion were used to summarise categorical variables; mean and standard deviation (SD) were reported for age and serum 25(OH)D concentration. We reported survey-weighted serum $25(\mathrm{OH}) \mathrm{D}$ concentration by season of blood collection, stratified by age group, as mean (95\% confidence interval $(\mathrm{CI})$ ). The prevalence of total serum 25 $(\mathrm{OH}) \mathrm{D}$ concentration $<50 \mathrm{nmol} / \mathrm{L}$ was reported stratified by age group. We also reported prevalence of serum 25(OH)D concentration $<50,50-<75$ and $\geq 75 \mathrm{nmol} / \mathrm{L}$ stratified by state/territory.

Independent predictors of vitamin D deficiency were determined using survey-weighted Poisson regression models at the individual level. Potential predictors of deficiency for adolescents were sex, age, region of birth, season, BMI and socioeconomic status (data for education and smoking were not available for 12-14 year olds; data for physical activity were not available for 12-17 year olds; hence, these variables were not included in the model for adolescents). Potential predictors of deficiency for young adults were sex, age, region of birth, season, BMI, smoking, education, physical activity and socioeconomic status. State/territory was not included in regression models, as numbers were small $(n<10)$ for three of the eight states/ territories when stratified by age group. Prevalence ratios (PRs) were obtained with robust variance based on the Huber sandwich estimate. Statistical analysis was conducted using Stata Statistical Software version 16 [28].

\section{Results}

The current study included adolescents and young adults aged 12-24 years who provided a blood sample for the NHMS and had complete data for all potential predictors. There were 4732 participants aged $12-24$ years in the AHS. Of these, 1166 had data for serum $25(\mathrm{OH}) \mathrm{D}$ concentration. A total of 74 participants had incomplete data for potential predictors, with missing data for BMI $(n=63)$, education $(n=10)$ and physical activity $(n=18)$. Hence, 1092 participants were included in the current study, consisting of 692 adolescents aged $12-17$ years and 400 young adults aged 18-24 years.

The majority of the participants $(81 \%)$ were born in Australia (Table 1). More than $70 \%$ of participants were categorised as underweight/healthy weight. More than half of the young adult population (55\%) had a high or moderate physical activity level. The majority of young adults (88\%) were ex-smokers or non-smokers.

The mean (SD) serum 25(OH)D concentration was 69.7 (36.8) $\mathrm{nmol} / \mathrm{L}$ for adolescents and $64.3(40.0) \mathrm{nmol} / \mathrm{L}$ for young adults. Across all seasons, mean serum 25(OH)D concentrations were lower in participants born in other regions that those born in Australia (Fig. 1).

A greater proportion of young adults (32\%) than adolescents $(17 \%)$ were vitamin $\mathrm{D}$ deficient (Table 1). The prevalence of deficiency was similar between males (29\%) and females (23\%) aged 12-24 years, and lowest in Queensland $\left(11^{\circ} \mathrm{S}-29^{\circ} \mathrm{S}\right)$ and highest in Victoria $\left(34^{\circ} \mathrm{S}-39^{\circ}\right.$ 
Table 1 Survey-weighted ${ }^{\mathrm{a}}$ descriptive characteristics of Australian adolescents $(12-17$ years; $n=692)$ and young adults $(18-24$ years; $n=400)$ included in the current study.

\begin{tabular}{|c|c|c|c|c|}
\hline \multirow[t]{2}{*}{ Characteristic } & \multicolumn{2}{|c|}{ Adolescents } & \multicolumn{2}{|c|}{ Young adults } \\
\hline & $n$ & $\%(95 \% \mathrm{CI})$ & $n$ & $\%(95 \% \mathrm{CI})$ \\
\hline \multicolumn{5}{|l|}{ Sex } \\
\hline Male & 339 & $51(45,56)$ & 186 & $52(46,59)$ \\
\hline Female & 353 & $49(44,55)$ & 214 & $48(41,54)$ \\
\hline Age, years, mean (SD) & $14.4(2.6)$ & & $20.9(2.0)$ & \\
\hline \multicolumn{5}{|l|}{ Serum $25(\mathrm{OH}) \mathrm{D}$ concentration $(\mathrm{nmol} / \mathrm{L})^{\mathrm{b}}$} \\
\hline$<50$ & 112 & $17(14,22)$ & 112 & $32(26,39)$ \\
\hline $50-<75$ & 333 & $48(42,53)$ & 145 & $35(29,42)$ \\
\hline$\geq 75$ & 247 & $35(30,40)$ & 143 & $33(27,39)$ \\
\hline \multicolumn{5}{|l|}{ Region of birth } \\
\hline Australia & 610 & $88(85,91)$ & 319 & $74(68,80)$ \\
\hline Other & 82 & $12(9,15)$ & 81 & $26(20,32)$ \\
\hline \multicolumn{5}{|l|}{ Education $^{\mathrm{c}}$} \\
\hline High/primary/no school & N/A & N/A & 218 & $54(48,61)$ \\
\hline Certificate/diploma & N/A & N/A & 98 & $26(20,32)$ \\
\hline University & N/A & N/A & 84 & $20(15,26)$ \\
\hline \multicolumn{5}{|l|}{ Smoking $^{c}$} \\
\hline Ex/non-smoker & N/A & N/A & 346 & $88(84,92)$ \\
\hline Current & N/A & N/A & 54 & $12(8,16)$ \\
\hline \multicolumn{5}{|l|}{ Socioeconomic status } \\
\hline Lowest quintile & 116 & $18(14,23)$ & 72 & $16(2,22)$ \\
\hline Second quintile & 117 & $16(13,20)$ & 90 & $23(18,29)$ \\
\hline Third quintile & 163 & $24(20,29)$ & 78 & $18(13,23)$ \\
\hline Fourth quintile & 149 & $20(16,25)$ & 59 & $14(10,19)$ \\
\hline Highest quintile & 147 & $22(18,27)$ & 101 & $29(23,36)$ \\
\hline \multicolumn{5}{|l|}{ Physical activity $^{\mathrm{c}}$} \\
\hline High & N/A & N/A & 105 & $27(21,33)$ \\
\hline Moderate & N/A & N/A & 123 & $28(23,34)$ \\
\hline Low/sedentary & N/A & N/A & 172 & $45(39,51)$ \\
\hline \multicolumn{5}{|l|}{ Body mass index category } \\
\hline Underweight/healthy weight $\left(<25 \mathrm{~kg} / \mathrm{m}^{2}\right)$ & 512 & $74(68,78)$ & 264 & $71(65,76)$ \\
\hline Overweight $\left(25-<30 \mathrm{~kg} / \mathrm{m}^{2}\right)$ & 129 & $20(16,25)$ & 85 & $19(15,25)$ \\
\hline Obese $\left(\geq 30 \mathrm{~kg} / \mathrm{m}^{2}\right)$ & 51 & $6(4,9)$ & 51 & $10(6,14)$ \\
\hline \multicolumn{5}{|l|}{ Season } \\
\hline Summer (December-February) & 176 & $26(21,31)$ & 108 & $25(20,31)$ \\
\hline Autumn (March-May) & 219 & $31(27,37)$ & 127 & $32(26,38)$ \\
\hline Winter (June-August) & 196 & $30(25,35)$ & 107 & $26(21,33)$ \\
\hline Spring (September-November) & 101 & $13(10,16)$ & 58 & $17(12,22)$ \\
\hline
\end{tabular}

$25(\mathrm{OH}) \mathrm{D}$ 25-hydroxyvitamin D, $\mathrm{CI}$ confidence interval, N/A not applicable, $S D$ standard deviation.

apercentages are weighted to the Australian population in 2011-2013.

${ }^{b}$ Based on year-round blood collection, with each person sampled on one occasion only.

${ }^{\mathrm{c}}$ Variable not reported for all ages of adolescents.
S). Table 2 shows the characteristics of participants with vitamin D deficiency (serum 25(OH)D concentrations < $50 \mathrm{nmol} / \mathrm{L}$ ). A further $48 \%$ of adolescents and $35 \%$ of young adults had serum 25(OH)D concentrations 50 $<75 \mathrm{nmol} / \mathrm{L}$. Only $4 \%$ of adolescents and $3 \%$ of young adults had serum $25(\mathrm{OH}) \mathrm{D}$ concentrations $>125 \mathrm{nmol} / \mathrm{L}$ (Fig. 2).

In Poisson regression models (with all potential predictors included in the model), the prevalence of vitamin D deficiency was more than double for participants born in 


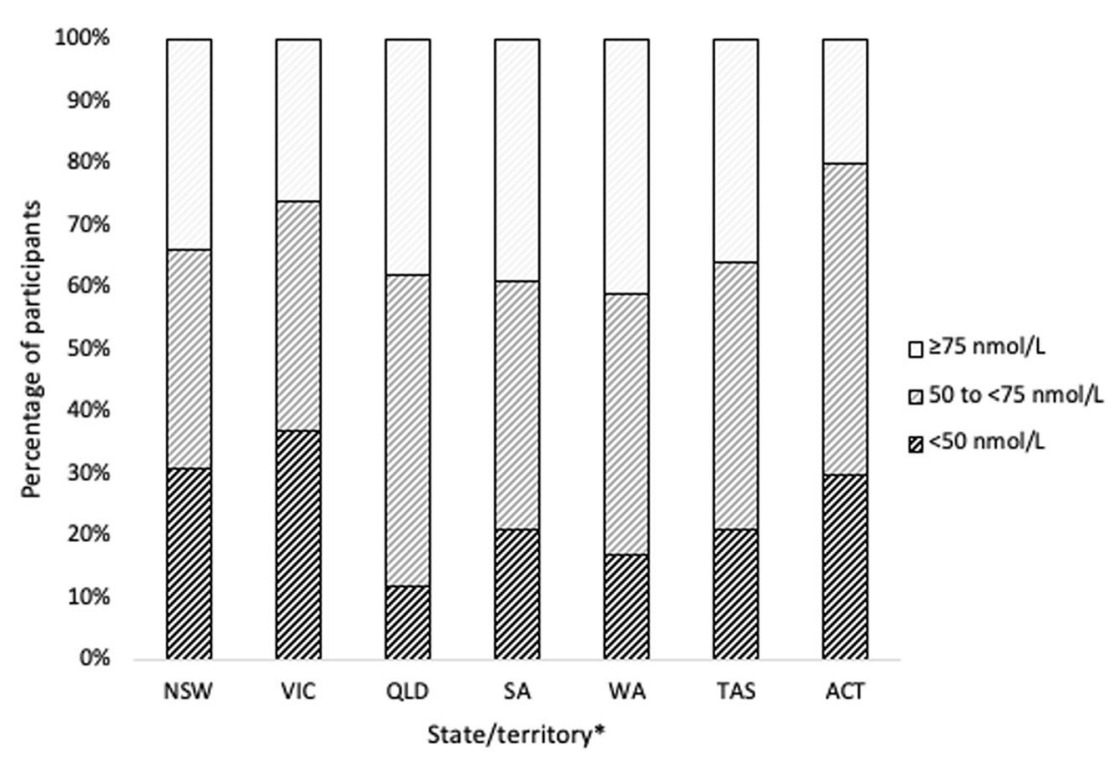

Fig. 1 Mean serum 25-hydroxyvitamin D concentrations (with 95\% CI) by season of blood collection in participants aged 12-24 years born in Australia $(n=929)$ and other regions $(n=163)$ included in the current study. Summer, December-February; autumn, March-May; winter, June-August; spring, September-November.

countries other than Australia compared with those born in Australia (Tables 3 and 4). Overweight adolescents were approximately twice as likely to have vitamin D deficiency compared to underweight/healthy weight adolescents (Table 3). Adolescents with blood samples taken in spring or winter had at least double the risk of vitamin D deficiency compared to those with measurements taken in summer. In young adults, the risk of vitamin D deficiency was three times greater for those with blood samples taken in winter compared to summer, and approximately doubled in those with low/sedentary or moderate physical activity levels compared to those with high physical activity levels (Table 4).

\section{Discussion}

In this nationally representative sample of Australian adolescents and young adults, $17 \%$ of adolescents and $32 \%$ of young adults were vitamin D deficient. The latter is higher than in any other age group in the AHS (e.g. 29\% in 25-34 year olds, $23 \%$ in $35-44$ year olds, $21 \%$ in $45-54$ year olds, $17 \%$ in $55-64$ year olds, $15 \%$ in $65-74$ year olds, $19 \%$ in those aged $\geq 75$ years) [19]. By comparing our prevalence data with the 2011 census population data [29], we estimate that 280,000 adolescents aged $12-17$ years had a serum 25 $(\mathrm{OH}) \mathrm{D}$ concentration $<50 \mathrm{nmol} / \mathrm{L}$ in 2011 . A similar comparison suggests that $\sim 650,000$ young adults aged $18-24$ years had a serum $25(\mathrm{OH}) \mathrm{D}$ concentration $<50 \mathrm{nmol} / \mathrm{L}$ in 2011.

Previous studies of children and adolescents in Australia suggest that the prevalence of vitamin D deficiency increases with higher latitude: low prevalence in children in the Northern Territory $\left(12^{\circ} \mathrm{S}-26^{\circ} \mathrm{S}\right)[30]$ and adolescents in Western Australia $\left(15^{\circ} \mathrm{S}-35^{\circ} \mathrm{S}\right)$ [31] and higher prevalence in Victoria $\left(34^{\circ} \mathrm{S}-39^{\circ} \mathrm{S}\right)$ [32] and Tasmania $\left(41^{\circ} \mathrm{S}-43^{\circ} \mathrm{S}\right)$ [33]. In our study, participants living in Victoria had the highest prevalence of vitamin D deficiency compared to participants living in other states and territories; we were not able to look at state/territory as a predictor of vitamin D deficiency in adjusted models due to small sample sizes in some states/territories.

Prevailing weather conditions [34], season and other potential confounders complicate the relationship between latitude and prevalence of vitamin D deficiency. Indeed, season was an independent predictor of vitamin D deficiency in both adolescents and young adults, which supports previous studies of children and/or adolescents in Australia [35], Norway [36] and the USA [37], where the prevalence of vitamin D deficiency was higher in winter than summer. Lower UV irradiance in winter (due to the tilt of the Earth's axis and the elliptical orbit of the Earth) reduces the potential for cutaneous synthesis of vitamin D. Furthermore, cloud coverage blocks the UV radiation from reaching the surface of the Earth [34]. This can also be an issue with the rainy season (during summer) in tropical locations, e.g. parts of Queensland and the Northern Territory, where ambient UV radiation is lower than expected due to greater cloud cover. Conversely, a study in the United Arab Emirates showed that the mean (SD) serum 25 $(\mathrm{OH}) \mathrm{D}$ concentration for female university students (mean (SD) age 20.8 (4.0) years) was higher during winter (31.3 (12.3) $\mathrm{nmol} / \mathrm{L})$ than during summer (20.9 (14.9) nmol/L) [38]. This finding was attributed to extreme heat avoidance 
Table 2 Survey-weighted ${ }^{\mathrm{a}}$ descriptive characteristics of Australian adolescents (12-17 years; $n=112)$ and young adults $(18-24$ years; $n=112)$ with vitamin $\mathrm{D}$ deficiency (serum $25(\mathrm{OH}) \mathrm{D}<50 \mathrm{nmol} / \mathrm{L})$.

\begin{tabular}{|c|c|c|c|c|}
\hline \multirow[t]{2}{*}{ Characteristics } & \multicolumn{2}{|c|}{ Adolescents } & \multicolumn{2}{|c|}{ Young adults } \\
\hline & $n$ & $\%(95 \% \mathrm{CI})$ & $n$ & $\%(95 \% \mathrm{CI})$ \\
\hline \multicolumn{5}{|l|}{ Sex } \\
\hline Male & 61 & $53(40,65)$ & 63 & $59(47,70)$ \\
\hline Female & 51 & $47(35,60)$ & 49 & $41(30,53)$ \\
\hline Age, years, mean (SD) & $14.6(3.2)$ & & $21.1(2.1)$ & \\
\hline \multicolumn{5}{|l|}{ Region of birth } \\
\hline Australia & 81 & $76(65,85)$ & 65 & $50(38,62)$ \\
\hline Other & 31 & $24(15,35)$ & 47 & $50(38,62)$ \\
\hline \multicolumn{5}{|l|}{ Education $^{\mathrm{b}}$} \\
\hline High/primary/no school & N/A & N/A & 60 & $55(43,67)$ \\
\hline Certificate/diploma & N/A & N/A & 23 & $17(10,27)$ \\
\hline University & N/A & N/A & 29 & $28(18,40)$ \\
\hline \multicolumn{5}{|l|}{ Smoking $^{\mathrm{b}}$} \\
\hline Ex/non-smoker & N/A & N/A & 95 & $81(69,89)$ \\
\hline Current & N/A & N/A & 17 & $19(11,31)$ \\
\hline \multicolumn{5}{|l|}{ Socioeconomic status } \\
\hline Lowest quintile & 25 & $25(14,39)$ & 19 & $19(11,31)$ \\
\hline Second quintile & 18 & $16(9,26)$ & 23 & $24(15,36)$ \\
\hline Third quintile & 26 & $18(11,28)$ & 20 & $16(9,28)$ \\
\hline Fourth quintile & 18 & $16(8,28)$ & 18 & $12(7,21)$ \\
\hline Highest quintile & 25 & $26(16,39)$ & 32 & $29(19,41)$ \\
\hline \multicolumn{5}{|l|}{ Physical activity ${ }^{\mathrm{b}}$} \\
\hline High & N/A & N/A & 15 & $14(7,24)$ \\
\hline Moderate & N/A & N/A & 36 & $33(23,46)$ \\
\hline Low/sedentary & N/A & N/A & 61 & $53(41,65)$ \\
\hline \multicolumn{5}{|l|}{ Body mass index category } \\
\hline Underweight/healthy weight $\left(<25 \mathrm{~kg} / \mathrm{m}^{2}\right)$ & 71 & $60(46,72)$ & 74 & $74(63,83)$ \\
\hline Overweight $\left(25.0-<30 \mathrm{~kg} / \mathrm{m}^{2}\right)$ & 28 & $31(19,45)$ & $18(12)$ & $12(6,20)$ \\
\hline Obese $\left(\geq 30 \mathrm{~kg} / \mathrm{m}^{2}\right)$ & 13 & $9(4,20)$ & $20(14)$ & $14(7,25)$ \\
\hline \multicolumn{5}{|l|}{ Season } \\
\hline Summer (December-February) & 16 & $16(9,28)$ & 13 & $11(5,22)$ \\
\hline Autumn (March-May) & 20 & $23(12,38)$ & 28 & $24(15,36)$ \\
\hline Winter (June-August) & 47 & $41(29,54)$ & 51 & $48(36,60)$ \\
\hline Spring (September-November) & 29 & $20(12,30)$ & 20 & $17(10,27)$ \\
\hline
\end{tabular}

25(OH)D 25-hydroxyvitamin D, CI confidence interval, N/A not applicable, $S D$ standard deviation.

${ }^{\text {a }}$ Percentages are weighted to the Australian population in 2011-2013.

${ }^{\mathrm{b}}$ Variable not reported for all ages of adolescents. and cultural tendencies towards full-coverage clothing [38] and demonstrates that increased opportunity for sun exposure does not necessarily result in higher serum $25(\mathrm{OH}) \mathrm{D}$ concentrations.

Compared with adults aged $\geq 25$ years [19], we found similar predictors of vitamin D deficiency in adolescents and young adults, including region of birth other than Australia, winter/spring season of blood collection, being overweight and low physical activity. The higher risk of deficiency seen in individuals born in regions other than Australia could be attributed to cultural clothing habits leading to reduced sun exposure [38] or to darker skin. Individuals with darker skin have a higher melanin concentration which limits cutaneous vitamin D synthesis; hence, those with darker skin require a longer duration or higher intensity of exposure to UV radiation to synthesise adequate vitamin D [39].

The relationship between obesity, physical activity and vitamin D deficiency is unclear; however, both physical activity and vitamin D status may influence bone mineral density $[1,40]$. The use of survey data to monitor physical activity trends in Australia is complicated by the use of 


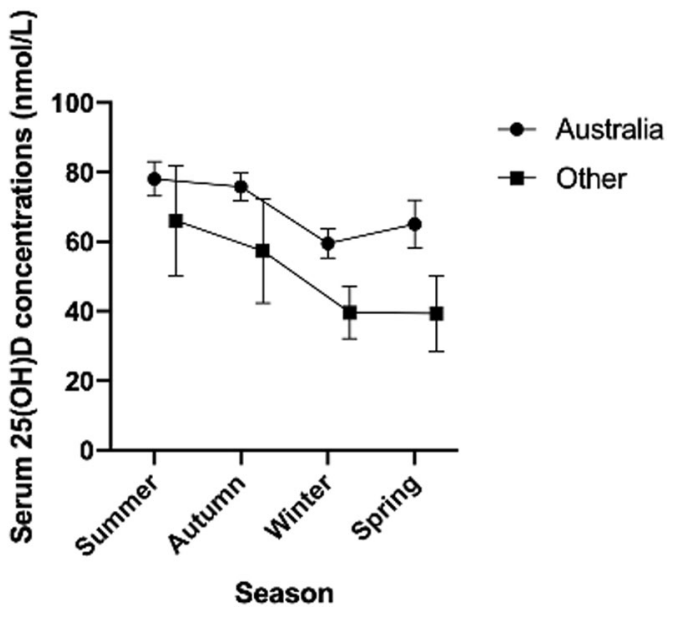

Fig. 2 Percentage of participants aged 12-24 years with serum 25hydroxyvitamin D concentrations $<50,50-<75$ and $\geq 75 \mathrm{nmol} / \mathrm{L}$ by state/territory (weighted to the Australian population in 2011-2013). NSW $n=167$, VIC $n=158$, QLD $n=175$, SA $n=148$, WA $n=152$, TAS $n=141$, ACT $n=93$. *Northern territory excluded since $n<10$ in one or more categories.

various methods to score physical activity levels [41], and it is not clear whether Australians are becoming more or less physically active over time [42, 43]. Furthermore, determination of any potential association between trends in physical activity and vitamin D deficiency could be compromised by use of non-standardised assays to measure serum $25(\mathrm{OH}) \mathrm{D}$ concentrations.

Low physical activity levels may be associated with reduced time spent outdoors, resulting in lower sun exposure [44]; low physical activity itself is a risk factor for overweight/obesity [45]. It has also been suggested that a higher fat mass leads to vitamin D deficiency through volumetric dilution of $25(\mathrm{OH}) \mathrm{D}$ [46]. We previously reported that being obese and having low physical activity levels were independent predictors of vitamin D deficiency in Australian adults aged $\geq 25$ years [19]. Similarly, in adults aged $\geq 18$ years participating in the 2001-2010 National Health and Nutrition Examination Survey (NHANES), obesity and low physical activity were independent predictors of vitamin D deficiency [47]. However, in the current study, there was no statistically significant association between BMI category and risk of vitamin D deficiency in young adults in adjusted analyses, whereas those with low/sedentary or moderate physical activity levels were approximately twice as likely to be vitamin D deficient as those with high physical activity levels. In contrast, overweight adolescents were approximately twice as likely to be vitamin D deficient as those of healthy weight; however, we were not able to adjust for physical activity since it was not collected for adolescents. Obesity was also an independent predictor of vitamin D deficiency
Table 3 Survey-weighted Poisson regression model showing independent predictors of vitamin D deficiency (serum 25(OH)D concentrations $<50 \mathrm{nmol} / \mathrm{L}$ ) in adolescents aged $12-17$ years who were included in the current study $(n=692)$.

\begin{tabular}{lll}
\hline Characteristics & PR $(95 \% \mathrm{CI})$ & $P$ value \\
\hline Sex & & \\
$\quad$ Male & Reference & \\
Female & $0.92(0.60,1.39)$ & 0.68 \\
Age & $1.05(0.91,1.20)$ & 0.53 \\
Region of birth & & \\
$\quad$ Australia & Reference & \\
Other & $2.46(1.59,3.81)$ & $<0.001$ \\
Socioeconomic status & & \\
Lowest quintile & Reference & \\
Second quintile & $0.64(0.33,1.23)$ & 0.18 \\
Third quintile & $0.59(0.30,1.15)$ & 0.12 \\
Fourth quintile & $0.57(0.27,1.25)$ & 0.16 \\
$\quad$ Highest quintile & $0.80(0.41,1.58)$ & 0.52 \\
Body mass index category & & \\
Underweight $/ \mathrm{healthy} \mathrm{weight}\left(<25 \mathrm{~kg} / \mathrm{m}^{2}\right)$ & Reference & \\
Overweight $\left(25-<30 \mathrm{~kg} / \mathrm{m}^{2}\right)$ & $1.97(1.19,3.24)$ & 0.008 \\
Obese $\left(\geq 30 \mathrm{~kg} / \mathrm{m}^{2}\right)$ & $1.98(0.86,4.55)$ & 0.11 \\
Season & & \\
Summer & Reference & \\
Autumn & $0.99(0.45,2.16)$ & 0.98 \\
Winter & $2.01(1.03,3.92)$ & 0.040 \\
Spring & $2.47(1.22,5.01)$ & 0.012 \\
\hline
\end{tabular}

Summer, December-February; autumn, March-May; winter, June-August; spring, September-November.

$P R$ prevalence ratio, $C I$ confidence interval.

in children and adolescents aged 1-21 years in the 2001-2004 NHANES; however, similar to our study, physical activity was not assessed [5].

Our findings that vitamin D deficiency affects a considerable proportion of Australian adolescents and young adults indicate that measures may be required to improve circulating $25(\mathrm{OH}) \mathrm{D}$ concentrations in this population. These findings are based on 25(OH)D measurements made using an assay certified to the RMPs and may provide a more reliable picture of vitamin D status than screening by the non-certified assays that are commonly used for routine assessment of individuals [15]. These routinely used assays often provide $25(\mathrm{OH}) \mathrm{D}$ results lower than the true value and may result in supplements being provided to those that do not require them [15]. Addition of vitamin D into the food supply though food fortification or biofortification may be a more suitable approach than supplementation, which is more appropriate as a treatment for frank deficiency at the individual level [15]. This would allow provision of safe but useful amounts of vitamin D across the Australian population, which would then benefit adults in older age brackets that are also affected by vitamin D deficiency [19].

A major strength of our study was the use of an assay certified to the RMPs. A further strength was the large 
Table 4 Survey-weighted Poisson regression model showing predictors of vitamin D deficiency (serum 25(OH)D concentrations $<50 \mathrm{nmol} / \mathrm{L}$ ) in young adults aged $18-24$ years who were included in the current study $(n=400)$.

\begin{tabular}{|c|c|c|}
\hline Characteristics & PR $(95 \% \mathrm{CI})$ & $P$ value \\
\hline \multicolumn{3}{|l|}{ Sex } \\
\hline Male & Reference & \\
\hline Female & $0.78(0.55,1.10)$ & 0.16 \\
\hline Age & $1.00(0.91,1.11)$ & 0.95 \\
\hline \multicolumn{3}{|l|}{ Region of birth } \\
\hline Australia & Reference & \\
\hline Other & $2.12(1.46,3.07)$ & $<0.001$ \\
\hline \multicolumn{3}{|l|}{ Education } \\
\hline High school & Reference & \\
\hline Certificate & $0.79(0.48,1.31)$ & 0.36 \\
\hline University & $0.96(0.0 .62,1.48)$ & 0.84 \\
\hline \multicolumn{3}{|l|}{ Smoking } \\
\hline Ex/non-smoker & Reference & \\
\hline Current & $1.37(0.89,2.12)$ & 0.15 \\
\hline \multicolumn{3}{|l|}{ Socioeconomic status } \\
\hline Lowest quintile & Reference & \\
\hline Second quintile & $0.99(0.61,1.59)$ & 0.96 \\
\hline Third quintile & $0.74(0.43,1.28)$ & 0.28 \\
\hline Fourth quintile & $0.83(0.49,1.42)$ & 0.50 \\
\hline Highest quintile & $1.00(0.61,1.62)$ & 0.98 \\
\hline \multicolumn{3}{|l|}{ Physical activity } \\
\hline High & Reference & \\
\hline Moderate & $2.02(1.11,3.69)$ & 0.02 \\
\hline Low/sedentary & $2.34(1.27,4.31)$ & 0.007 \\
\hline \multicolumn{3}{|l|}{ Body mass index category } \\
\hline Underweight/healthy weight & Reference & \\
\hline Overweight & $0.69(0.42,1.11)$ & 0.12 \\
\hline Obese & $1.12(0.64,1.95)$ & 0.69 \\
\hline \multicolumn{3}{|l|}{ Season } \\
\hline Summer & Reference & \\
\hline Autumn & $1.46(0.71,3.00)$ & 0.30 \\
\hline Winter & $3.32(1.69,6.53)$ & 0.001 \\
\hline Spring & $2.07(0.99,4.29)$ & 0.05 \\
\hline
\end{tabular}

Summer, December-February; autumn, March-May; winter, June-August; spring, September-November.

$P R$ prevalence ratio, $C I$ confidence interval.

nationally representative sample of Australian adolescents and young adults with blood samples taken year round; previous studies in Australia have been limited to specific regions or limited seasons. The AHS provided comprehensive data on demographic and lifestyle characteristics, which allowed for potential predictors of vitamin D deficiency to be investigated. Although the AHS provided the most recent nationally representative serum $25(\mathrm{OH}) \mathrm{D}$ concentrations in adolescents and young adults, some years have since passed and sun exposure practices may have changed over time. Indeed, data from National Sun Protection Surveys show that proportions of adults and adolescents who reported getting sunburnt and who reported using two or more sun protective behaviours on summer weekends increased between 2011 and 2013 (sunburn: adults $7 \%$, adolescents $13 \%$; sun protective behaviours: adults 42\%, adolescents 23\%) and 2016 and 2017 (sunburn: adults $11 \%$, adolescents $16 \%$; sun protective behaviours: adults $45 \%$, adolescents $35 \%$ ) [48]. We were not able to consider some potential predictors, since they were either not collected in the AHS (vitamin D intakes; skin pigmentation; sun exposure) or the sample numbers were low (country of origin other than Australia or years lived in Australia (for immigrants)). Comparison between regions of birth classified as "Australia" or "Other" may not account for potential regional or racial/ethnic differences within these categories. We were able to estimate prevalences for states and territories; however, many of the states and territories span a wide latitude and we were unable to explore the effects of geographic variability within states and territories on vitamin D status.

In conclusion, we found that $17 \%$ of adolescents and $32 \%$ of young adults in Australia were vitamin D deficient. Region of birth other than Australia and season of blood collection were independent predictors of deficiency in both age groups. In Australia, screening for vitamin D deficiency is recommended only for those at high risk of deficiency (e.g. children and people with: osteoporosis; osteomalacia; a condition that affects, or requires medication that may affect vitamin D absorption or reduce circulating $25(\mathrm{OH}) \mathrm{D}$ concentrations; darker skin pigmentation; reduced sun exposure) [49]. Recommending supplementation at the population level is not an ideal public health strategy since adherence to supplement use is poor and is not necessarily adopted by those most at risk of deficiency [50]. Therefore, given the importance of adequate vitamin $\mathrm{D}$ for bone health, there is a need to develop and promote strategies to maintain adequate vitamin $\mathrm{D}$ status through safe sun exposure and dietary approaches, particularly for young adults.

Acknowledgements The Australian Health Survey was conducted by the Australian Bureau of Statistics (ABS) with funding provided through the ABS health survey programme, the Department of Health and the National Heart Foundation of Australia. The authors would like to thank the Australian Health Survey participants for their time and contribution to the survey. The authors acknowledge Paul Atyeo and Barry Tynan (ABS) for their advice and assistance in using data from the Australian Health Survey.

Funding RML is supported by an Australian National Health and Medical Research Council Senior Research Fellowship. LJB is supported by a Multiple Sclerosis Research Australia Postdoctoral Fellowship and a Curtin University Research Fellowship. ED would like to acknowledge the Australian Government Research Training Program Scholarship in supporting this research. GP was supported with 
funding from the National Health and Medical Research Council Project and Investigator Grants \#1099655 and \#1173991 and the Research Council of Norway through its Centres of Excellence funding scheme \#262700.

Author contributions RML and LJB: conceptualization; KHF and LJB: formal analysis and methodology; GP: statistical support; KH-F: wrote the manuscript; ED, RML, GP and LJB: manuscript review and editing and LJB: supervision.

\section{Compliance with ethical standards}

Conflict of interest The authors declare no competing interests.

Publisher's note Springer Nature remains neutral with regard to jurisdictional claims in published maps and institutional affiliations.

\section{References}

1. Zhu K, Oddy WH, Holt P, Ping-Delfos WCS, Mountain J, Lye S, et al. Tracking of vitamin D status from childhood to early adulthood and its association with peak bone mass. Am J Clin Nutr. 2017;106:276-83.

2. Palacios C, Kostiuk LK, Peña-Rosas JP. Vitamin D supplementation for women during pregnancy. Cochrane Database Syst Rev. 2019;7:CD008873.

3. Martineau AR, Jolliffe DA, Greenberg L, Aloia JF, Bergman P, Dubnov-Raz G, et al. Vitamin D supplementation to prevent acute respiratory infections: individual participant data meta-analysis. Health Technol Assess. 2019;23:1-44.

4. Grant WB, Lahore H, McDonnell SL, Baggerly CA, French CB, Aliano JL, et al. Evidence that vitamin D supplementation could reduce risk of influenza and COVID-19 infections and deaths. Nutrients. 2020;12:988.

5. Kumar J, Muntner P, Kaskel FJ, Hailpern SM, Melamed ML. Prevalence and associations of 25-hydroxyvitamin D deficiency in US children: NHANES 2001-2004. Pediatrics. 2009;124:e362-70.

6. Saintonge S, Bang H, Gerber LM. Implications of a new definition of vitamin D deficiency in a multiracial us adolescent population: the National Health and Nutrition Examination Survey III. Pediatrics. 2009; 123:797-803.

7. Ford ES, Zhao G, Tsai J, Li C. Associations between concentrations of Vitamin D and concentrations of insulin, glucose, and HbA1c among adolescents in the United States. Diabetes Care. 2011;34:646-8.

8. Kelishadi R, Ardalan G, Motlagh ME, Shariatinejad K, Heshmat $\mathrm{R}$, Poursafa $\mathrm{P}$, et al. National report on the association of serum vitamin $\mathrm{D}$ with cardiometabolic risk factors in the pediatric population of the Middle East and North Africa (MENA): the CASPIAN-III Study. Nutrition. 2014;30:33-38.

9. Shin YH, Kim KE, Lee C, Shin HJ, Kang MS, Lee H-R, et al. High prevalence of vitamin D insufficiency or deficiency in young adolescents in Korea. Eur J Pediatr. 2012;171:1475-80.

10. Wu F, Laslett LL, Zhang Q. Threshold effects of vitamin D status on bone health in Chinese adolescents with low calcium intake. J Clin Endocrinol Metab. 2015;100:4481-9.

11. Al-Musharaf S, Al-Othman A, Al-Daghri NM, Krishnaswamy S, Yusuf DS, Alkharfy KM, et al. Vitamin D deficiency and calcium intake in reference to increased body mass index in children and adolescents. Eur J Pediatr. 2012;171:1081-6.

12. Aypak C, Türedi Ö, Yüce A. The association of vitamin D status with cardiometabolic risk factors, obesity and puberty in children. Eur J Pediatr. 2014;173:367-73.
13. Binkley N, Krueger DC, Morgan S, Wiebe D. Current status of clinical 25-hydroxyvitamin D measurement: an assessment of between-laboratory agreement. Clin Chim Acta. 2010;411:1976-82.

14. Black LJ, Anderson D, Clarke MW, Ponsonby AL, Lucas RM, Ausimmune, et al. Analytical bias in the measurement of serum 25-hydroxyvitamin D concentrations impairs assessment of vitamin D status in clinical and research settings. PLoS ONE. 2015;10:e0135478.

15. Lucas R, Neale R. What is the optimal level of vitamin D?: Separating the evidence from the rhetoric. Aust Fam Physician. 2014;43:119-22.

16. Lai JKC, Lucas RM, Banks E, Ponsonby AL, Ausimmune Investigator Group. Variability in vitamin D assays impairs clinical assessment of vitamin D status. Intern Med J. 2012;42:43-50.

17. Sempos CT, Vesper HW, Phinney KW, Thienpont LM, Coates PM, Vitamin D, Standardization Program. Vitamin D status as an international issue: national surveys and the problem of standardization. Scand J Clin Lab Investig. 2012;243:32-40.

18. Mineva EM, Schleicher RL, Chaudhary-Webb M, Maw KL, Botelho JC, Vesper HW, et al. A candidate reference measurement procedure for quantifying serum concentrations of 25hydroxyvitamin $\mathrm{D}(3)$ and 25-hydroxyvitamin $\mathrm{D}(2)$ using isotope-dilution liquid chromatography-tandem mass spectrometry. Anal Bioanal Chem. 2015;407:5615-24.

19. Malacova E, Cheang PR, Dunlop E, Sherriff JL, Lucas RM, Daly $\mathrm{RM}$, et al. Prevalence and predictors of vitamin D deficiency in a nationally-representative sample of adults participating in the 20112013 Australian Health Survey. Br J Nutr. 2019;121:894-904.

20. Australian Bureau of Statistics. Australian health survey: users' guide 2011-12. Canberra: Australian Government; 2013. https://www.abs.gov.au/ausstats/abs@.nsf/mf/4363.0.55.001.

21. Cole TJ, Bellizzi MC, Flegal KM, Dietz WH. Establishing a standard definition for child overweight and obesity worldwide: international survey. BMJ. 2000;320:1240.

22. Cole TJ, Flegal KM, Nicholls D, Jackson AA. Body mass index cut offs to define thinness in children and adolescents: international survey. BMJ. 2007;335:194.

23. Daly RM, Gagnon C, Lu ZX, Magliano DJ, Dunstan DW, Sikaris $\mathrm{KA}$, et al. Prevalence of vitamin D deficiency and its determinants in Australian adults aged 25 years and older: a national, population-based study. Clin Endocrinol. 2012;77:26-35.

24. Horton-French K, Dunlop E, Lucas RM, Pereira G, Black LJ. Prevalence and predictors of vitamin D deficiency among African immigrants living in Australia. Int J Environ Res Public Health. 2019;16:2855.

25. Institute of Medicine. Dietary reference intakes for calcium and vitamin D. Washington, DC: The National Academies Press; 2011.

26. McDonnell SL, Baggerly CA, French CB, Baggerly LL, Garland $\mathrm{CF}$, Gorham ED, et al. Breast cancer risk markedly lower with serum 25-hydroxyvitamin D concentrations $\geq 60$ vs $<20 \mathrm{ng} / \mathrm{ml}$ $(150 \mathrm{vs} 50 \mathrm{nmol} / \mathrm{L})$ : pooled analysis of two randomized trials and a prospective cohort. PLoS ONE. 2018;13:e0199265.

27. Mirhosseini N, Vatanparast H, Kimball S. The association between serum $25(\mathrm{OH}) \mathrm{D}$ status and blood pressure in participants of a community-based program taking vitamin D supplements. Nutrients. 2017;9:1244.

28. StataCorp. Stata statistical software: release 16. College Station, TX: StataCorp LLC; 2019.

29. Australian Bureau of Statistics. Census of population and housing 2011, TableBuilder. Australian Bureau of Statistics; 2016. https://www.abs.gov.au/websitedbs/censushome.nsf/home/ta blebuilder?opendocument \&navpos $=240$.

30. Dyson A, Pizzutto SJ, Maclennan C, Stone M, Chang AB. The prevalence of vitamin D deficiency in children in the Northern Territory. J Paediatr Child Health. 2014;50:47-50. 
31. Black LJ, Burrows SA, Jacoby P, Oddy WH, Beilin LJ, PingDelfos WCS. et al. Vitamin D status and predictors of serum 25hydroxyvitamin D concentrations in Western Australian adolescents. Br J Nutr. 2014;112:1154-62.

32. Kwon DH, Krieser D, Harris C, Khot A, Ebeling PR, Rodda CP. High prevalence of vitamin D deficiency in 2-17 year olds presenting with acute fractures in southern Australia. Bone Rep. 2016;5:153-7.

33. Jones G, Dwyer T, Hynes KL, Parameswaran V, Greenaway TM. Vitamin D insufficiency in adolescent males in Southern Tasmania: prevalence, determinants, and relationship to bone turnover markers. Osteoporos Int. 2005;16:636-41.

34. Kimlin MG. Geographic location and vitamin D synthesis. Mol Asp Med. 2008;29:453-61.

35. Ke L, Mason RS, Baur LA, Cowell CT, Liu X, Garnett SP, et al. Vitamin D levels in childhood and adolescence and cardiovascular risk factors in a cohort of healthy Australian children. J Steroid Biochem Mol Biol. 2018;177:270-7.

36. Lagunova Z, Porojnicu AC, Lindberg FA, Aksnes L, Moan J. Vitamin D status in Norwegian children and adolescents with excess body weight. Pediatr Diabetes. 2011;12:120-6.

37. Rajakumar K, de Las Heras J, Chen TC, Lee S, Holick MF, Arslanian SA. Vitamin D status, adiposity, and lipids in black American and Caucasian children. J Clin Endocrinol Metab. 2011;96:1560-7.

38. Al Anouti F, Thomas J, Abdel-Wareth L, Rajah J, Grant WB, Haq A. Vitamin D deficiency and sun avoidance among university students at Abu Dhabi, United Arab Emirates. Dermatoendocrinology. 2014;3:235-9.

39. Clemens TL, Adams JS, Henderson SL, Holick MF. Increased skin pigment reduces the capacity of skin to synthesise vitamin D3. Lancet. 1982;1:74-76.

40. Alghadir AH, Gabr SA, Al-Eisa E. Physical activity and lifestyle effects on bone mineral density among young adults: sociodemographic and biochemical analysis. J Phys Ther Sci. 2015;27:2261-70.

41. Bauman A, Chau J. Monitoring population trends through physical activity surveillance-a chequered history in Australia. Australas Epidemiol. 2015;22:5-8.

42. Lincoln D, Clemens S, Roselli T, Bright M. Declining trends in adult physical activity in Australia? An alternative view. Aust N Z J Public Health. 2018;42:216-216.

43. Chau J, Chey T, Burks-Young S, Engelen L, Bauman A. Trends in prevalence of leisure time physical activity and inactivity: results from Australian National Health Surveys 1989 to 2011. Aust N Z J Public Health. 2017;41:617-24.

44. Al-Othman A, Al-Musharaf S, Al-Daghri Nasser M, Krishnaswamy S, Yusuf Deqa S, Alkharfy, et al. Effect of physical activity and sun exposure on vitamin D status of Saudi children and adolescents. BMC Pediatrics. 2012;12:92.

45. Pietiläinen $\mathrm{KH}$, Kaprio J, Borg $P$, Plasqui G, Yki-Järvinen $H$, Kujala UM, et al. Physical inactivity and obesity: a vicious circle. Obesity. 2008;16:409-14.

46. Drincic AT, Armas LAG, Van Diest EE, Heaney RP. Volumetric dilution, rather than sequestration best explains the low vitamin $\mathrm{D}$ status of obesity. Obesity. 2012;20:1444-8.

47. Liu X, Baylin A, Levy PD. Vitamin D deficiency and insufficiency among US adults: prevalence, predictors and clinical implications. Br J Nutr. 2018;119:928-36.

48. Cancer Australia. Sunburn and sun protection. Cancer Australia; 2019. https://ncci.canceraustralia.gov.au/prevention/sun-exposure/ sunburn-and-sun-protection.

49. Boyages SC. Vitamin D testing: new targeted guidelines stem the overtesting tide. Med J Aust. 2016;204:18-18.

50. Yetley E, Pfeiffer C, Schleicher R, Phinney K, Lacher D, Christakos S. et al. NHANES monitoring of serum 25-hydroxyvitamin D: a roundtable summary. J Nutr. 2010;140:2030S-45S. 